\title{
Evidence of hantavirus infection in wild rodents captured in a rural area of the state of São Paulo, Brazil ${ }^{1}$
}

\author{
Elba Regina S. de Lemos², Paulo S. D'Andrea³, Cibele R. Bonvicino³, Kátia M. \\ Famadas ${ }^{4}$, Paula Padula ${ }^{5}$, Adauto A. Cavalcanti ${ }^{6}$ and Hermann G. Schatzmayr ${ }^{2}$
}

\begin{abstract}
Lemos E.R.S., D'Andrea P.S., Bonvicino C. R., Famadas K. M., Padula P., Cavalcanti A.A. \& Schatzmayr H.G. 2004. Evidence of hantavirus infection in wild rodents captured in a rural area of the state of São Paulo, Brazil. Pesqui sa Veterinária Brasileira 24(2):71-73. Depto Virologia, Instituto Oswaldo Cruz, Av. Brasil 4365, Pavilhão Rocha Lima, 5o andar, Manguinhos, Rio de Janeiro, RJ, 21045-900, Brazil. E-mail: elemos@ ioc.fiocruz.br

Hantaviruses are the etiological agents of the Hantavirus Cardio-Pulmonary Syndrome, a serious rodent-borne disease in Brazil. In order to investigate the occurrence of hantavirus infection in wild rodents, a survey was conducted in three different suburban areas of the municipality of Pedreira, State of São Paulo, Brazil. Of the 145 wild animals captured belonging to 12 different species identified by morphology and karyological analysis, 107 were rodents of the following species: Akodon montensis, Bolomys lasiurus, Calomys tener, Oligoryzomys nigripes, Oligoryzomys flavescens, and Myocastor coypus. Blood samples from these rodents were assayed for the presence of antibodies against hantavirus by IgG ELISA using Andes recombinant nucleocapsid antigen. Antibody reactive to Andes virus was found in two different species, 0. nigripes and 0 . flavescens. These results indicate a potential risk for hantavirus transmission to humans in this area, where reservoir rodents are present in peridomestic settings.
\end{abstract}

INDEX TERMS: Hantavirus, rodent, survey, Pedreira, São Paulo, Brazil.

RESUMO.- [Evidência de infecção por hantavírus em roedores silvestres capturados em uma área rural do estado de São PauIo, Brasil.] Hantavírus éo agente etiológico da síndrome cardiopulmonar por hantavirus (SCPH), uma importante doença transmitida por roedores no Brasil. Com o objetivo de se conhecer a ocorrência de infecção por hantavírus em pequenos roedores silvestres, uma análise sorológica foi conduzida em três diferentes áreas do subúrbio da cidade de Pedreira, São Paulo. Dos 145 animais silvestres capturados, pertecentes a 12 diferentes espécies identificadas por morfologia e por análise cariológica, 107 eram roedores das seguintes espécies: Akodon montensis,

\footnotetext{
${ }^{1}$ Received on September 23, 2003.

Accepted for publication on October 24, 2003

${ }^{2}$ Depto Virologia, Instituto Oswaldo Cruz, FIOCRUZ, Avenida Brasil 4365, Manguinhos, Rio de Janeiro, RJ 21045-900. E-mail: elemos@ ioc.fiocruz.br

${ }^{3}$ Depto Medicina Tropical Instituto Oswaldo Cruz, FIOCRUZ.

${ }^{4}$ Depto Parasitologia Animal, Universidade Federal Rural do Rio de Janeiro, Seropédica, RJ 23890-000.

${ }^{5}$ Instituto Nacional de Laboratórios e Instituto de Saúde Dr. Carlos Málbran, Buenos Aires, Argentina.

${ }^{6}$ Secretaria de Saúde e de Meio Ambiente do Município de Pedreira, São Paulo, SP 13920-000.
}

Bolomys lasiurus, Calomys tener, Oligoryzomys nigripes, Oligoryzomys flavescens, e Myocastor coypus. Amostras de sangue desses roedores foram testadas para a presença de anticorpos $\lg \mathrm{G}$ contra o antígeno do nucleocapsídeo do vírus Andes através do teste ELISA. Reatividade sorológica ao vírus Andes foi observada em duas espécies diferentes, 0 . nigripes and 0 . flavescens. Estes resultados indicam o potencial risco de transmissão de hantavírus nesta região, onde roedores reservatórios freqüentemente são vistos em peridomicílio.

TERM OS DE INDEXAÇÃO: Hantavírus, roedores, prevalência, Pedreira, São Paulo, Brasil.

\section{INTRODUCTION}

Hantavirus cardiopulmonary syndrome (HCPS), a newly recognized viral disease that has been described in the American continent since 1993, is caused by several strains of the genus Hantavirus, family Bunyaviridae (Nichol et al. 1993, Elliott et al. 1994, Spiropoulou et al. 1994). A number of hantavirus serotypes (Sin Nombre, Black Creek Canal, Bayou, Andes, Laguna Negra, Rio Mamore, Juquitiba, Araraquara, Franca and Castelo dos Sonhos), among other hantaviruses, has been identified in different American countries (Lee et al. 1978, Rollin et al. 1995, Gonzalez- 
Scarano \& Nathanson 1996, Lopez et al. 1996, Bharadwaj et al. 1997, Johnson et al. 1997, Schamaljohn \& Hjelle 1997, Silva et al. 1997, Vasconcelos et al. 1997, Levis et al. 1998, Johnson et al. 1999).

The natural reservoirs for hantaviruses in the Americas are rodents of the family Muridae, subfamily Sigmodontinae (Butler \& Peters 1994, Morzunov et al. 1995, Rowe et al. 1995, Schamaljohn \& Hjelle 1997, Mills et al. 1998, 1999, Young et al. 1998, Nichol 2001). In Brazil, rodents harbouring infection by hantaviruses have been detected by serological methods in different regions, where certain rodent species - mainly Bolomys lasiurus, Akodon cursor and Oligoryzomys nigripes - have been considered as important natural reservoirs for the virus (Ferreira et al. 1998, Johnson et al., 1999, Figueiredo et al. 2001, Romano-Liber et al. 2001).

Considering the scarce information about hantaviruses in Brazil, this study was conducted in reach for evidences of hantavirus infection in wild rodents in the region of Pedreira, State of São Paulo, Brazil, where HCPS had to date not been reported.

\section{MATERIALS AND METHODS}

This study was carried out in the County of Pedreira, located in the southeast of the State of São Paulo, Brazil, an area within the Brazilian Atlantic Forest domain, near the limits with the Cerrado Biome, at $22^{\circ} 44^{\prime} 21^{\prime \prime}$ latitude South and $46^{\circ} 54^{\prime} 27^{\prime \prime}$ longitude West, 584m above sea level. The vegetation of this area has been altered mainly due to farming activities. Eucalyptus, high-growing grass, swamp and secondary forest were common .

Three localities were sampled: the Workers' Colony of Nadir Figueiredo Industry (NF), Fortaleza Farm (FF), and Jaguari Farm (JF), located along Jaguari River, $3 \mathrm{~km}$ away from the nearest urban center.

Field surveys were done in January 1996 and April/May and October 1997, totalling a capture effort of 1,830 trap-nights. Sherman and Tomahawk live traps were spaced at approximately every 10 meters in linear ground transects. The bait was a mixture of bacon, peanut butter, oatmeal and banana. Mammal specimens were karyotyped to confirm morphological identification. Chromosome preparations were obtained from short term bone marrow cultures with $80 \%$ RPMI 1640, 20\%fetal calf serum, ethidium bromide (5 mg/ $\mathrm{ml}$ ) and colchicine $10^{-6} \mathrm{M}$ (Bonvicino et al. 1996).

All species of rodents were analysed for antibodies against hantavirus by IgG ELISA using ANDES antigen (Padula et al. 2000). The recombinant nucleocapsid protein was applied to the solid phase of a microtiter plate. After washing, serum samples were added. After 1hour incubation at $37^{\circ} \mathrm{C}$ plates were washed again and a mixture of two conjugates (anti-Peromyscus leucopus IgG and antiRattus norvegicus IgG, Kirkegaard and Perry Laboratories) was used to detect immunoglobulins from various rodent phyla. The chromogenic substrate used was 2,2'-azino-di(3-ethyl-benzthiazoline sulfonate) (Kirkegaard and Perry Laboratories). Optical densities were read at 405 and $450 \mathrm{~nm}$. A titer $>/=1: 400$ was considered positive (Padula et al. 2000). Subsequently, lung tissue and blood samples from seropositive rodents were analysed for virus RNA by reverse transcriptase-polymerase chain reaction (RT-PCR; Lopez et al. 1996).

\section{RESULTS}

One hundred and fourty-five wild animals belonging to 12 different species were identified by morphology and karyological analysis and were subsequently deposited in the National Museum, Rio de Janeiro, Brazil. The following species were captured: the marsupials Didel phis aurita (18), Didelphis marsupialis (6), Gracilinanus microtarsus (1), Lutreolina crassicaudata (15), Monodelphis sorex (1), the rodents Bolomys lasiurus (24), Akodon montensis (35), Nectomys squamipes (21), Oligoryzomys nigripes (16), Oligoryzomys flavescens (4), Calomys tener (2) and Myocastor coypus (2) The overall trapping success for all species was 7.4\% Only rodents were assayed for the presence of antibodies to Andes recombinant antigen (ELISA). From 107 rodents submitted to serological testing, two individuals, one 0 . nigripes and one 0 . flavescens, captured in the Nadir Figueiredo area, had evidence of hantavirus infection with an antibody titer equal to or greater than 1:1600. These seropositive animals represented $10.0 \%(2 / 20)$ of genus Oligoryzomys captured in that county. Lung tissues and blood samples from these rodents did not reveal the presence of hantavirus genoma by RT-PCR.

\section{DISCUSSION}

Although human cases of HCPS have not been reported in the county where this study was undertaken, several facts highlight the need to analyse the status of hantavirus infections in this region: 1) the usual contact of the human population with wild rodents in rural areas, 2) rural touristic activities, and 3) large farming areas. In fact, all rodents should be considered as potentially infected, since some reports have demonstrated hantavirus infections in small mammal populations without confirmed HPS human cases (Lee et al. 1982, LeDuck et al. 1985, Mills et al. 1998). Thus, the risk for hantavirus infection should be considered whenever individuals are frequently exposed to wild rodents.

The result of the present study suggest that seropositive Oligoryzomys rodent may be in a late stage of infection, when the immune response decreases the amount of viral antigen (Netski et al. 1999), although the lack of RNA detection through PCR may have been due to the fact that samples had been frozen and thawed several times. Even though the identity of the virus detected by serological tests could not be determined, the results obtained in this preliminary report suggest that rodents captured in peridomestic environments of Pedreira can be reservoirs of pathogenic hantaviruses. Further investigations should be carried out in different regions in Brazil for a better understanding of the distribution of such infection in the country.

Acknowledgments.- The authors wish to thank Mr. Alexandre Adabo, and the Mayor's Office of Pedreira, State of São Paulo, for their cooperation in the fieldwork.

\section{REFERENCES}

Bharadwaj M., Botten J., Torrez-Martinez N. \& Hjelle B. 1997. Rio Marmore virus: genetic characterization of a newly recognized hantavirus of the pygmy rice to rat, Olygoryzomys microtis, from Bolivia. Am. J. Trop. Med. Hyg. 57:368-374.

Bonvicino C.R., D'Andrea P.S., Cerqueira R. \& Seaunez H.N. 1996. The chromosomes of Nectomys (Rodentia, Cricetidae) with $2 n=52,2 n=56$, and interspecific hybrids $(2 n=54)$. Cytogen. Cell Genet. 73:190-193. 
Butler J.C. \& Peters C. J. 1994. Hantaviruses and hantavirus pulmonary syndrome. Clin. Infect. Dis. 19:387-395

Elliott L.H., Ksiazek T.G., Rollin P.E., Spiropoulou C.F., Morzunov S., Monroe M., Goldsmith C.S., Humphrey C.D., Zaki S.R. \& Krebs J.W. 1994. Isolation of the causative agent of hantavirus pulmonary syndrome. Am. J. Trop. Med. Hyg. 51:102-108.

Ferreira L. T., Pereira L.E. \& Suzuki A. 1998. Hantavirus Pulmonary Syndrome in São Paulo and Mato Grosso States, Brazil. Virus Rev. Res. 3 (Suppl.1):43. (Resumo)

Figueiredo L.T., Campos G.M. \& Rodrigues F.B. 2001. Hantavirus pulmonary and cardiovascular syndrome: epidemiology, clinical presentation, laboratory diagnosis and treatment. Revta Soc. Bras. Med. Trop. 34(1):13-23.

Gonzalez-Scarano F. \& Nathanson A. 1996. Bunyaviridae, p. 1473-1504. In: B.N. Fields et al. (ed.) Fields Virology. $3^{\text {rd }}$ Edition. Lippincott-Haven Publishers, Philadelphia, USA.

Jonhson A. M., Bowen M.D., Ksiazek T.G., Williams R.J., Bryan R.T., Mills J.N., Peters C.J. \& Nichol S.T. 1997. Laguna Negra virus associated with HPS in western Paraguay and Bolivia. Virology 238:115-127.

Johnson A.M., Souza L.T.M., Ferreira I.B., Pereira L.E., Ksiazek T.G., Rollin P.E., Peters C.J. \& Nichol S.T. 1999. Genetic investigation of novel hantavirus causing fatal HPS in Brazil. J. Med. Virol. 59:527-535.

LeDuc J.W., Smith G.A., Pinheiro F.P., Vasconcelos P.F., Rosa E.S. \& Maiztegui J.I. 1985. Isolation of a Hantaan-related virus from Brazilian rats and serological evidence of its widespread distribution in South America. Am. J. Trop. Med. Hyg. 34:810-815.

Lee H.W., Lee P. \& Johnson K.M. 1978. Isolation of the etiologic agent of Korean hemorrhagic fever. J. Infect. Dis. 137:298-308.

Lee H. W., Lee P. \& Johnson K.M. 1982. Isolation of Hantaan virus, the etiologic agent of Korean hemorrhagic fever. From wild urban rats. J. Infect. Dis. 146:638-644

Levis S., Morzunov S.P., Rowe J.E., Enria D., Pini N., Calderon G., Sabattini M. $\&$ Jeor S.C.S. 1998. Genetic diversity and epidemiology of hantavirus in Argentina. J. Infect. Dis. 177:529-538.

Lopez N., Padula P., Rossi C., Lazaro M.E. \& France-Fernandez M.T. 1996. Genetic identification of a new hantavirus causing severe pulmonary syndrome in Argentina. Virology 220:233-226.

Mills J.N. \& Childs J.E. 1998. Ecologic studies of rodent reservoirs: their relevance for human health. Emerg. Infect. Dis. 4:529-537.

Mills J.N., Johnson J.M., Kiasek T.G., Ellis B.A., Rollin P.E., Yates T.L., Mann M.O., Johnson M.R., Campbell M.L., Miyashiro J., Patrick J.M., Zyzak M., Lavender D., Novak M.G., Schmidt K., Peters C.J. \& Childs J.E. 1998. A survey of hantavirus antibody in small-mammal populations in selected United States National Parks. Am. J. Trop. Med. Hyg. 58:525-532.

Mills J. N., Ksiazek T.G., Peters C.J. \& Childs J.E. 1999. Long-term studies of hantavirus reservoir populations in the southwestern United States: a synthesis. Emerg. Infect. Dis. 5:135-42.

Morzunov S.P., Feldmann H., Spiropoulou C.F., Semenova V.A., Rollin P.E., Ksiazek T.G., Peters C..J. \& Nichol S.T. 1995. A newly recognized virus associated with fatal case of hantavirus pulmonary syndrome in Louisiana. J. Virol. 69:1980-1983.

Netski D., Thran B.H. \& Jeor S.C.S 1999. Sin Nombre Virus Pathogenesis in Peromyscus maniculatus. J. Virol. 73: 585-591.

Nichol S.T., Spiropoulou C.F., Morzunov S., Rollin P.E., Ksiazek T.G., Feldmann H., Sanchez A., Childs J.E., Zaki S. \& Peters C.J. 1993. Genetic identification of a hantavirus associated with an outbreak of acute respiratory illness. Science 262: 914-917.

Nichol S.T., Arikawa J. \& Kawaoka Y. 2000. Emerging viral diseases. Proc. Natl Acad. Sci. USA 97:12411-12412

Padula P.J., Rossi C.M., Della Valle M.O, Martinez P.V., Colavecchia S.B., Edelstein A., Miguel S.D., Rabinovich R.D. \& Segura E.L. 2000. Development and evaluation of a solid-phase enzyme immunoassay based on Andes hantavirus recombinant nucleoprotein. J. Med. Microb. 49:149-155.

Rollin P.E., Ksiazeck T.G., Elliot L.E., Ravkov E.V., Martin M.L., Morzunov S., Livingstone W., Monroe M., Glass G., Ruo S., Khan A.S., Childs J.E., Nichol S.T. \& Peters C.J. 1995. Isolation of Black Creek Canal virus, a new hantavirus from Sigmodon hispidus in Florida. J. Med. Virol. 46: 35-39.

Romano-Lieber N.S., Yee J. \& Helle B. 2001. Serologic survey for hantavirus infectious among wild animals in rural areas of São Paulo State. Revta Inst. Med. Trop. São Paulo 43:325-327.

Rowe J.E.S., Jeor S.C., Riolo J., Otteson E.W., Monroe M.C., Henderson W.W., Ksiazek T.G., Rollin P.E. \& Nichol S.T. 1995. Coexistence of several novel hantavirus in rodents indigenous to North America. Virology 213:122-130.

Schmaljohn C. \& Hjelle B. 1997. Hantaviruses: a global disease problem. Emerg. Infect. Dis. 3:95-104.

Silva M.V., Vasconcelos M.J., Hidalgo N.T., Veiga A.P., Canzian M., Marotto P.C. $\&$ De Lima V.C. 1997. Hantavirus pulmonary syndrome. Report of the first three cases in São Paulo, Brazil. Revta Inst. Med. Trop. São Paulo 39:231234.

Spirapoulou C.F., Morzuno S., Feldman H., Sanchez A., Peters C.J. \& Nichol S.T. 1994. Genome structure and variability of a virus causing hantavirus pulmonary syndrome. Virology 200:715-723.

Vasconcelos M.I., Lima V.P., Iversson L.B., Rosa M.D.B., Travassos Da Rosa A.P.A., Travassos Da Rosa E.S., Pereira L.E., Nassar E., Katz G., Matida L.H., Zaparoli M.A., Ferreira J.J.B. \& Peters C.J. 1997. Hantavirus pulmonar syndrome in the rural area of Juquitiba, São Paulo metropolitan area, Brazil. Revta Inst. Med. Trop. São Paulo 39:237-238.

Young J.C., Mills J.N., Enria D.A., Dolan N.E., Khan A.S. \& Ksiazek T.G. 1998. New World hantaviruses. Brit. Med. Bull. 54:659-73. 